\title{
Religioznost i neke dimenzije psihološke dobrobiti kod mladih
}

Mira Klarin*

mklarin@unizd.hr

https://orcid.org/0000-0003-4138-7531

Arkadiusz Krasicki**

arkadiusz.krasicki@gmail.com

https://orcid.org/0000-0002-6229-5233 https://doi.org/10.31192/np.18.2.1

UDK: 27-184.3:303.423-053.67

17.023.34-053.67:27-184.3

Izvorni znanstveni rad / Original scientific paper

Primljeno: 16. travnja 2020.

Prihvaćeno: 18. lipnja 2020.

Cilj ovog istraživanja bio je istraživanje uloge religioznosti u psihološkoj dobrobiti mladih. U tu svrhu povedeno je istraživanje na mladima prosječne dobi 20,74 godina (N=129). Primijenjeni su sljedeći mjerni instrumenti: Skala zadovoljstva životom, Skala smisla života, Kratka ljestvica religioznosti i Ljestvica slaganja s temeljnim načelima Biblije i Katoličke crkve. Rezultati provedenog istraživanja vode zaključku da je većina mladih religiozna, odnosno da se slaže s temeljnim biblijskim načelima nauka Katoličke crkve. Rezultati testiranja razlike u zadovoljstvu životom s obzirom na stupanj slaganja s temeljnim načelima Biblije $i$ Katoličke crkve pokazuju da su mladi koji se više slažu s tim načelima zadovoljniji životom. Nadalje, zadovoljstvo životom pozitivno je povezano sa procjenom smisla života, religioznošću i slaganjem s temeljnim načelima Katoličke crkve. Rezultati regresijske analize pokazuju da su smisao života i slaganje s temeljnim načelima Biblije i Katoličke crkve značajni prediktori zadovoljstva životom.

Ključne riječi: Biblija, načela Katoličke crkve, religioznost, smisao života, zadovoljstvo životom.

\footnotetext{
* Prof. dr. sc. Mira Klarin, Sveučilište u Zadru, Odjel za izobrazbu učitelja i odgojitelja, Ulica dr. F. Tuđmana 24i, HR-23000 Zadar.

**Doc. dr. sc. Arkadiusz Krasicki, Sveučilište u Zadru, Teološko-katehetski odjel, Ulica dr. F. Tuđmana 24i, HR-23000 Zadar.
} 


\section{Uvod}

Razvojni period kojega nazivamo mladost uključuje dob od 15 do 30 godina. ${ }^{1}$ Temeljna značajka mu je stjecanje zrelosti na svim područjima razvoja, tjelesnom, kognitivnom, emocionalnom i socijalnom. Cjelokupan proces sazrijevanje tijekom ovog perioda vodi k razvoju apstraktnog mišljenja, a time i drukčijem poimanja vjere, odnosno Boga, pokazujući interes mladih za biblijskim tekstom. Postavljajući pitanja o smislu života i u potrazi za smislom razvijaju se vjerovanja, simboli i rituali. ${ }^{2}$ Fowler razlikuje pet faza razvoja vjere. ${ }^{3}$ Predfaza odgovara prvim dvjema godinama života koje su određene formiranjem privrženosti između djeteta i skrbnika i ona čini temelj razumijevanja svijeta. Karakteristika ovog perioda života je nemogućnost razlikovanja unutarnjeg od vanjskog svijeta, pa stoga dijete nema sliku o samome sebi. U ovom periodu razvoja dijete ne može razumjeti pojam vjere.

Prvu fazu razvoja vjere Fowler smješta u period ranog djetinjstva i naziva je intuitivno-projektivnom te je možemo povezati s intuitivnim mišljenjem koje karakterizira rano djetinjstvo. ${ }^{4}$ Dijete stvara slike, a rituali i priče čine osnovu za stvaranje predodžbi i fantazija koje su karakteristične za ovu dob. Mogućnost stvaranja predodžbi i simbola omogućuje djetetu jasniju sliku vjere. Ova faza je obilježena primitivnim osjećajem religioznosti. ${ }^{5}$

U dobi od 7 do 11 godina dijete razlikuje unutarnji svijet fantazije i vanjsko okruženje te ulazi u mitsko-literarnu fazu razvoja vjere. Norme i sustav vrijednosti dijete internalizira, odnosno usvaja ih kao vlastite. U ovom razdoblju razvoj morala je na konvencionalnoj razini. Razvija se osjećaj za pravednost. Značajka ovog perioda jest shvaćanje da svako ponašanje koje u svojoj osnovi nije pravedno za posljedicu ima kaznu. Razvoj logičkog mišljenja djetetu omogućuje doživljaj Boga s vrlo konkretnom predodžbom. Zbog snažnog utjecaja autoriteta ovu se fazu naziva i autoritarnom religioznošću. ${ }^{6}$

Sljedeći je period mladost te odgovara trećoj razvojnoj fazi, sintetičko-konvencionalnoj. Karakteristika je ove faze razvoja propitivanje vlastitog identiteta pa tako i identiteta sebe kao vjernika. Razvoj apstraktnog mišljenja omogućuje mladoj osobi shvaćanje pojmova kao što su Bog, vjera, pravednost, beskonačnost. Tek u kasnoj mladosti osoba promišlja, propituje, uspoređuje i formira

${ }^{1}$ Usp. Mladi u Republici Hrvatskoj, https://www.youthpolicy.org/national/Croatia_2009_National_Youth_Program.pdf, (09.03.2020).

${ }^{2}$ Usp. James W. FOWLER, Stages of faith, New York, Harper \& Row, 1981, prema Laura E. BERK, Psihologija cjeloživotnog razvoja, Jastrebarsko, Naklada Slap, 2008, 587-588.

${ }^{3}$ Usp. isto, 590.

${ }^{4}$ Usp. isto.

${ }^{5}$ Usp. Ilija ŽIVKOVIĆ, Koncept Boga i religioznost kod djece i adolescenata u istraživanjima Piagetovog, Kohlbergovog i postpiagetovog kognitivnog pravca, Sociologija i prostor, 45 (2007) 3-4, 321-337, 326.

${ }^{6}$ Usp. isto, 330. 
osobnu ideologiju tražeći značenje. Pojam Boga sve više poprima moralne i etičke značajke. Propitivanje o Bogu u ovom periodu može rezultirati smanjenjem zanimanja za vjeru i to u situacijama kada mlada osoba uočava nesklad između onoga što se govori i onoga što se radi.

Sljedeća je faza razvoja vjere individualizirano-refleksivna i odgovara odrasloj dobi. Osoba oblikuje osobnu ideologiju aktivno propitujući i razmišljajući o vjerovanjima i vrijednostima. Postavljaju se pitanja o značenju religijskih rituala i simbola.

Posljednja faza razvoja vjere karakteristika je kasne odrasle dobi i Fowler ${ }^{7}$ je naziva konjunktivnom. Ova faza u skladu je s odnosom osobe prema svijetu općenito. Formiraju se stavovi i načela koji su univerzalni, postavljaju se pitanja o dobrobiti cijele zajednice. Karakteristika kasne odrasle dobi je borba za opće dobro i borba protiv nepravde.

\section{Religioznost mladih}

Gotovo dvije trećine mladih u provedenom istraživanju vjeru smatra vrlo važnom u svojemu životu. ${ }^{8}$ Pri tome više od polovice sudionika poimaju vjeru kao čovjekovu egzistencijalističku potrebu. Vjera im pomaže u suočavanju sa životnim teškoćama i omogućuje im odgovore na brojna životna pitanja. Zanimljivo je da $43 \%$ mladih smatra da vjera ima važnu ulogu u savladavanje životnih teškoća, dok $24,8 \%$ njih smatra da vjera ima izuzetno važnu ulogu u savladavanju životnih teškoća. Vjeru mladi povezuju s temeljnim ljudskim vrijednostima, kao što su nada, povjerenje, moral. Neka istraživanja govore o visokom postotku mladih (77 \%) koji vjeruju u Boga. ${ }^{9}$ Radi konstrukcije mjernog instrumenta za mjerenje religioznosti, provedeno je istraživanje o religijskoj orijentaciji mladih..$^{10}$ Pri tome, $51,9 \%$ mladih na pitanje vjeruju li u Boga odgovara s »vrlo često«, $41 \%$ njih vrlo često ima osjećaj da ih Bog čuva, dok njih $32,5 \%$ ponekad razmišlja o vjeri, religiji i Bogu. Trećina mladih smatra da im vjera često i vrlo često pomaže u suočavanju sa životnim teškoćama i problemima. Isti autori ističu da religioznost mladih u periodu od 1985. do 1999. raste. Istraživanje provedeno 2008. na uzorku nešto starijih sudionika (u dobi od 20 do 24 godine starosti) pokazuje da $67 \%$ mladih vjeruje da Bog postoji, dok njih

\footnotetext{
7 Usp. isto, 590.

${ }^{8}$ Usp. Valentina Blaženka MANDARIĆ, Religiozno iskustvo u životu adolescenata, https://www. pilar.hr/wp-content/images/stories/dokumenti/studije/3/s_3_riza_152.pdf, 158 (10.03.2020).

9 Usp. Dinka MARINOVIĆ JEROLIMOV, Religioznost, nereligioznost i neke vrijednosti mladih, u: Furio RADIN i dr. (ur.), Mladi uoči trećeg milenija, Zagreb, Institut za društvena istraživanja u Zagrebu, 2002, 79-124, 94.

${ }^{10}$ Usp. Petar BEZINOVIĆ, Ankica MARINOVIĆ BOBINAC, Dinka MARINOVIĆ JEROLIMOV, Kratka ljestvica religioznosti. Validacija na uzorku adolescenata, Društvena istraživanja, 14 (2005) 1-2, 135-153, 141-143.
} 
33 \% katkad posumnja u Božje postojanje. ${ }^{11}$ Istraživanje stupnja religioznosti mladih u Republici Srpskoj ${ }^{12}$ govori o visokom postotku mladih (83 \%) koji se izjašnjavaju da su religiozni ili jako religiozni. Svega 4,5\% mladih se izjašnjava nereligioznima, dok je kod 12,9 \% sudionika stav prema vjeri promjenjiv. Može se reći da je religioznost mladih prilično visoka, a - kako se čini - i u porastu je. ${ }^{13}$

\subsection{Neki korelati religioznosti}

Promatrajući religiju kao vrijednosni sustav sasvim je sigurno da je ona povezana s različitim aspektima ličnosti ${ }^{14}$ socijalnom prilagodbom, ${ }^{15}$ zadovoljstvom životom ${ }^{16}$ i psihološkom dobrobiti. ${ }^{17}$ Štoviše, religijski stav je čovjekova trajna osobina koja čini njegovu ličnost. ${ }^{18}$

Od brojnih korelata religioznosti osobito se ističu spol i dob. Naime, brojna su istraživanja pokazala da su žene religioznije od muškaraca. ${ }^{19}$ Življenje i izražavanje vjere snažnije je izraženo kod žena nego kod muškaraca. ${ }^{20}$ Jedan od mogućih razloga veće religioznosti žena vjerojatno leži u procesu socijalizacije. Okruženje u kojemu živimo kod žena više potiče religiozno ponašanje, jer je obilježeno poniznošću i poslušnošću. Ali žene su, s druge strane, i otvorenije za duhovnost. Nadalje, moguće je i da prilikom provođenja ovakvih istraživanja sudionici daju socijalno poželjne odgovore, a to je nepriznavanje svoje religioznosti kod muškaraca. Sljedeće što svakako treba uzeti u obzir jest odnos spola i dobi sudionika. S obzirom da se s dobi duhovnost i religioznost povećavaju, kako kod žena tako i kod muškaraca, razlike s obzirom na spol postaju zasigurno manje. Međutim, rezultati nekih drugih istraživanja ne idu ovome u prilog. Tako, na primjer, rezultati istraživanja provedenog na uzorku starosti od 15 do 29 godina pokazuju nepostojanje razlika s obzirom na spol i na dob sudionika

${ }^{11}$ Usp. Zdravka LEUTAR, Ana Marija JOSIPOVIĆ, Neke dimenzije religioznosti mladih, Nova prisutnost, 6 (2008) 3, 397-421, 405.

${ }^{12}$ Usp. Srđan DUŠANIĆ, Religioznost i određeni korelati mentalnog zdravlja mladih, Godišnjak za psihologiju, 9 (2012) 11, 57-68, 62.

${ }^{13}$ Usp. Marinović Jerolimov, Religioznost, nereligioznost..., 120.

${ }^{14}$ Usp. Srđan DUŠANIĆ, Lana VUJAKOVIĆ, Đorđe ČEKRLIJA, Uloga etnocentrizma, religioznosti i socio-demografskih karakteristika u zadovoljstvu životom mladih, u: Đorđe ČEKRLIJA (ur.), Ličnost i društvo, V., Sarajevo, Friedrich-Ebert-Stiftung, 2019, 9-24, 19.

${ }^{15}$ Usp. Bezinović, Marinović Bobinac, Marinović Jerolimov, Kratka ljestvica religioznosti..., 137.

${ }^{16}$ Usp. Dušanić, Vujaković, Čekrlija, Uloga etnocentrizma, religioznosti..., 18-19.

${ }^{17}$ Usp. Daniela VILLANI i dr., The Role fo Spirituality and Religiosity in Subjective Well-Being of Individuals With Different Religious Status, Frontiers Psychology, (2019), https://www.frontiersin.org/articles/10.3389/fpsyg.2019.01525/full, 8 (16.03.2020).

${ }^{18}$ Usp. Štefica BAHTIJAREVIĆ, Neke karakteristike religioznosti i ateizma kod učenika srednjih škola, Revija za sociologiju, 1 (1971) 2, 40-52, 40.

${ }^{19}$ Usp. Bezinović, Marinović Bobinac, Marinović Jerolimov, Kratka ljestvica religioznosti..., 147.

${ }^{20}$ Usp. Mandarić, Religiozno iskustvo u životu adolescenata..., 169. 
u religijskoj samoidentifikaciji. ${ }^{21}$ Budući da nisu nađene razlike u religijskoj samoidentifikaciji s obzirom na dob, mogli bismo zaključiti da je ovaj razvojni period relativno stabilan glede razvoja religioznosti i duhovnosti, odnosno da su mladi ove dobi relativno homogena skupina kada govorimo o ovom aspektu religioznosti. Na kognitivnom planu razvija se kritičnost, propituju se vrijednosti koje su prisutne u okolini, internaliziraju se vrijednosti ili odbacuju. $\mathrm{Na}$ koncu se formira sustav vlastitih vrijednosti. Istovremeno je mlada osoba okupirana drugim razvojnim zadaćama - poput završetka školovanja, izlaska u svijet rada ili nastavka školovanja, ulaska u partnerski odnos i formiranja obitelji.

Zadovoljstvo životom i psihološka dobrobit sljedeći je korelat religioznosti. Zadovoljstvo životom jest »kognitivna evaluacija cjelokupnog života, a kroz koju svaki pojedinac procjenjuje svoj vlastiti živ«.22 Drugim riječima, to zadovoljstvo je opća procjena vlastitoga života, a temelji se na procjenama pojedinih aspekata života. Može se pretpostaviti da je ovo relativno stabilna osobina pojedinca. ${ }^{23}$ Međutim, istraživanja stabilnosti zadovoljstva životom u ovisnosti o dobi ne daju konzistentne rezultate. Tako se u literaturi može pronaći da nema značajnih promjena $u$ zadovoljstvu životom s obzirom na dob, ${ }^{24}$ da je zadovoljstvo životom veće kod mladih ${ }^{25}$ te da su najzadovoljniji oni u dobi od 40 do 70 godina starosti, dok nakon 70 . godine zadovoljstvo životom naglo opada. ${ }^{26}$ Zadovoljstvo duhovnim životom jedan je od značajnih aspekata zadovoljstva koji značajno doprinosi objašnjenju i razumijevanju globalnog zadovoljstva životom. ${ }^{27}$ Objašnjavajući ovu povezanost, autori navode da je vjera važan izvor podrške, pomaže u suočavanju sa stresom, značajan je poticaj za zdrav stil života te doprinosi osjećaju smisla. Vjera doprinosi blagostanju i daje smisao životu te time doprinosi većem zadovoljstvu životom..$^{28} \mathrm{U}$ razvojnom periodu mladosti, kada mlada osoba formira sliku o sebi i pokušava shvatiti tko je i što želi, vjera i duhovni život sigurno doprinose odgovoru na postavljena pitanja, a time i zadovoljstvu životom.

${ }^{21}$ Usp. Marinović Jerolimov, Religioznost, nereligioznost..., 85.

${ }^{22}$ Zvjezdan PENEZIĆ, Skala zadovoljstva životom, u: Katica LACKOVIĆ-GRGIN i dr. (ur.), Zbirka psihologijskih skala i upitnika, Zadar, Filozofski fakultet, 2002, 20-22, 20.

${ }^{23}$ Usp. Zvjezdan PENEZIĆ, Izabela SORIĆ, Skala temporalnog zadovoljstva životom, u: Vera ČUBELA ADORIĆ i dr. (ur.), Zbirka psihologijskih skala i upitnika, Zadar, Sveučilište u Zadru, 2006, 55-65, 55.

${ }^{24}$ Usp. Maryam CHEHREGOSHA i dr., Life satisfaction index among elderly people residing in gorganandits correlation with certain demographic factors in 2013, Global Journal of Health Science, 8 (2016) 41-49, 49.

${ }^{25}$ Usp. Christel BORG, Ingalill HALLBERG, Kerstin BLOMQIST, Life satisfaction among older people $(65+)$ with reduced self-care capacity: the relationship to social, health and financial aspects, Journal of clinical nursing, 15 (2006) 607-618, 612-613.

${ }^{26}$ Usp. Brendan BAIRD, Richard LUCAS, M. DONNELLAN, Life satisfaction across the life span: findings from two nationally representative panel studies, Social Indicators Research, 99 (2010) 2, 183-203, 195.

${ }^{27}$ Usp. Tihana BRKLJAČIĆ, Ljiljana KALITERNA LIPOVČAN, Zadovoljstvo životom i osjećaj sreće kod studenata, Suvremena psihologija, 13 (2010) 2, 189-201, 197.

${ }^{28}$ Usp. Dušanić, Vujaković, Čekrlija, Uloga etnocentrizma, religioznosti..., 20. 
Istražujući odnos između duhovnosti i religioznosti, s jedne strane, i subjektivne dobrobiti koja je operacionalizirana kao zadovoljstvo životom, s druge strane, nađena je značajna povezanost između duhovnosti i subjektivne dobrobiti. ${ }^{29}$ Unutarnja snaga proizašla iz duhovnosti smanjuje posljedice negativnih iskustava. Nadalje, posjedovanje vjerskog identiteta pozitivno je povezano sa zadovoljstvom životom. Procjena dobrobiti i svakodnevna iskustva razlikuju se kod osoba koje su vjernici i osoba koje to nisu. Vjernici svoj život procjenjuju pozitivnijim i više uživaju u svakodnevnim iskustvima od osoba koje nisu vjernici. $^{30}$

\section{Cilj i problemi istraživanja}

$\mathrm{S}$ obzirom na značajnu ulogu vjere $u$ formiranje identiteta mladih i činjenicu da vjera kod mladih ima sve veće značenje, cilj ovog istraživanja bio je ispitati odnos između religioznosti, zadovoljstva životom i psihološke dobrobiti kod mladih. Postavili smo više istraživačkih pitanja: Prvo istraživačko pitanje odnosilo se na procjenu religioznosti kod mladih. Drugo istraživačko pitanje bilo je usmjereno na ispitivanje razlika u zadovoljstvu životom $\mathrm{s}$ obzirom na stupanj slaganja s temeljnim načelima Biblije i Katoličke crkve. Sljedeće istraživačko pitanje odnosilo se na ispitivanje povezanosti između mjerenih varijabli. Posljednje istraživačko pitanje odnosilo se na provjeru prediktivne vrijednosti religioznosti, slaganja s temeljnim načelima Biblije i Katoličke crkve i procjene smisla života u procjeni zadovoljstva svojim životom.

\section{Metoda istraživanja}

\subsection{Sudionici istraživanja}

U istraživanju je sudjelovalo ukupno 129 studenata dvaju sveučilišta, Sveučilišta u Osijeku (N=64) i Sveučilišta u Zadru $(\mathrm{N}=65)$. Od ukupnog broja sudionika mladića je bilo 42 (32,56 \%), a djevojaka 87 (67,44 \%), prosječne dobi 20,74, raspona od 18 do 28 godina.

\footnotetext{
${ }^{29}$ Usp. Villani i dr., The Role of Spirituality and Religiosity..., 8.

${ }^{30}$ Usp. Chaeyoon LIM, Religion, Time Use and Affctive Well-Being, Sociologicl Science, 3 (2016) 685-709, 703-704.
} 


\subsection{Mjerni instrumenti}

\section{Kratka ljestvica religioznosti ${ }^{31}$}

Kratka ljestvica religioznosti ima pet tvrdnji koje mjere vjerovanja, odnosno religioznu orijentaciju. Zadatak je sudionika da na mjernoj ljestvici od 5 stupnjeva procijeni učestalost pojave navedenih tvrdnji o vjerovanju u Boga, odnosno odredi učestalost svojega religioznog doživljaja pri čemu 1 označava nikad, a 5 vrlo često. Autori iznose podatak o zadovoljavajućoj pouzdanosti ljestvice. Karakteristična tvrdnja glasi: Vjerujem u Boga. Ljestvica pokazuje jednofaktorsku strukturu sa zadovoljavajućom pouzdanošću Cronbach alpha $=0,91$. Veći rezultat na ljestvici označava veću razinu religioznosti.

\section{Ljestvica slaganja s temeljnim načelima Biblije i Katoličke crkve (TNBKC) $)^{32}$}

$\mathrm{U}$ svrhu ovog istraživanja konstruirana je ljestvica slaganja s TNBKC radi mjerenja stupnja slaganja s navedenim temeljnim načelima. Sadrži 12 tvrdnji na koje sudionici odgovaraju prema ljestvici od 5 stupnjeva, pri čemu 1 označava uopće se ne slažem, a 5 u potpunosti se slažem. Karakteristična tvrdnja glasi: Po svojoj naravi čovjek je religiozno biće. Ljestvica slaganja s TNBKC pokazuje jednofaktorsku strukturu sa zadovoljavajućom pouzdanošću Cronbach alpha = 0,97 . Također, valja istaknuti da ljestvica ima sadržajnu valjanost jer su tvrdnje temeljene na Katekizmu Katoličke crkve (KKC). Osvrnut ćemo se na tri tvrdnje ove ljestvice: Po svojoj naravi čovjek je religiozno biće, Bog je ljubav i Bog je svemoguć. Čežnja za Bogom upisana je u čovjekovo srce jer je čovjek - Adam - stvoren na Božju sliku (Post 1,27), stoga neprestano traga za Bogom svjesno ili nesvjesno (Dj 17,26-28). Bog je ljubav (1 Iv 4,8.16), ljubav je, tako reći, Božja narav. Tako sv. Ivan definira Boga u svojoj poslanici. Time ukazuje na to da se čovjek, koji je stvoren za ljubav, može približiti Bogu da ga slijedi i osjeća njegovu zaštitu. Božja je ljubav prava ljubav koja sjedinjuje Boga i čovjeka. ${ }^{33}$ Budući da je Bog svemoguć tako je i njegova ljubav svemoguća. On rasipno dijeli svoju milost svakome tko traži.

Ljestvica ima i konstruktivnu valjanost jer je korelacija između rezultata na ovoj ljestvici i rezultata na Kratkoj ljestvici religioznosti značajna i visoka $\mathrm{r}=$ 0,91 . Veći rezultat na ljestvici interpretira se kao veći stupanj slaganja s temeljnim biblijskim načelima i načelima Katoličke crkve.

\footnotetext{
${ }^{31}$ Bezinović, Marinović Bobinac, Marinović Jerolimov, Kratka ljestvica religioznosti..., 140-141. (Ljestvicu i dopuštenje za njezino korištenje u ovom istraživanju dao je njezin autor.)

${ }^{32}$ Zbog jasnoće, prilikom navođenja imena ljestvice i predmeta njezina mjerenja u daljnjem tekstu ćemo koristiti kraticu TNBKC.

${ }^{33}$ Usp. Albin ŠKRINJAR, Teologija svetog Ivana, Zagreb, 1975, 63-68.
} 


\section{Skala zadovoljstva životom ${ }^{34}$}

Skala ima 17 tvrdnji na koje sudionici odgovaraju na ljestvici Likertovog tipa, pri čemu 1 označava uopće se ne slažem, dok 5 označava $u$ potpunosti se slažem. Linearnim zbrajanjem procjena dobiva se ukupno opće zadovoljstvo životom, pri čemu veći rezultat označava veće zadovoljstvo. Autor skale ističe njezinu jednofaktorsku strukturu i relativno visoku pouzdanost. U ovom istraživanju dobili smo trofaktorsku strukturu, ali sa značajnom projekcijom svih tvrdnji na prvom faktoru, stoga smo skalu tretirali kao jednofaktorsku. Pouzdanost skale iznosi Cronbach alpha $=0,90$. Karakteristična tvrdnja glasi: Zadovoljan sam svojim životom, te veći rezultat na skali označava veće zadovoljstvo životom.

\section{Skala psihološke dobrobiti ${ }^{35}$}

Autorica originalne skale je Ryff. ${ }^{36}$ Skala ima čest supskala, ali za potrebe ovoga istraživanja koristili smo samo jednu i to supskalu smisla života. Supskala sadrži pet tvrdnji koje se odnose na osjećaj smisla i svrhe života i životnih ciljeva. Sudionici odgovaraju na ljestvici Likertovog tipa od 6 stupnjeva, pri čemu 1 znači izrazito se ne slažem, a 5 izrazito se slažem s navedenom tvrdnjom. Skala pokazuje jednofaktorsku strukturu i zadovoljavajuće je pouzdanosti Cronbach alpha $=0,78$. Karakteristična tvrdnja glasi: Imam osjećaj smjera $i$ svrhe života. Veći rezultat na skali označava veći osjećaj smislenosti života.

\section{Rezultati i rasprava}

Prvi korak u statističkoj obradi podataka bila je deskriptivna statistika s kojom smo odgovorili na prvo istraživačko pitanje koje se odnosi na razinu religioznosti kod mladih (tablica 1). Budući da nema statistički značajne razlike između mladića i djevojaka u procjenama na svim ljestvicama, rezultati su prikazani skupno za oba spola.

Promatrajući rezultate na pojedinim ljestvicama možemo zaključiti da su studenti relativno zadovoljni životom, umjereno su religiozni te se umjereno slažu s TNBKC. Također ocjenjuju svoj život smislenim i usmjerenim nekom cilju.

\footnotetext{
${ }^{34}$ Penezić, Skala zadovoljstva životom..., 22.

${ }^{35}$ Andreja BRAJŠA-ŽGANEC, Danijela IVANOVIĆ, Josip BURUŠIĆ, Dimenzije psihološke dobrobiti hrvatskih studenata: spolne razlike i povezanost s osobinama ličnosti, Napredak, 155 (2014) 1-2, 29-46, 34-35.

${ }^{36}$ Caroll RYFF, Happiness is everything, or is it? Explorations on the meaning of psychological well-being, Journal of Personality and Social Psychology, 57 (1989) 6, 1069-1081; doi:10.1037/0022-3514.57.6.1069. (Originalna skala kao i dopuštenje za njezino korištenje u ovom istraživanju dobiveno je od autorice.)
} 
Tablica 1 - Rezultati deskriptivne statistike za mjerene varijable ( $\mathrm{N}=129)$

\begin{tabular}{|l|c|c|c|c|c|}
\hline & Minimalno & Maksimalno & M & SD & Cronbach alpha \\
\hline Zadovoljstvo životom & 33 & 84 & 3,92 & 9,06 & 0,90 \\
\hline Religioznost & 5 & 25 & 3,54 & 5,96 & 0,91 \\
\hline Načela Katoličke crkve & 12 & 60 & 3,69 & 14,77 & 0,97 \\
\hline Smisao života & 7 & 30 & 4,56 & 4,24 & 0,78 \\
\hline
\end{tabular}

Budući da nas je osobito zanimala religioznost kod mladih, analizirali smo distribucije rezultata na ljestvici religioznosti i ljestvici slaganja s TNBKC (grafikon 1 i 2). Kao što se iz rezultata može zaključiti, obje distribucije su pomaknute prema većim vrijednostima, što znači da je većina mladih religiozna te da se uvelike slažu s temeljnim načelima Biblije i Katoličke crkve.

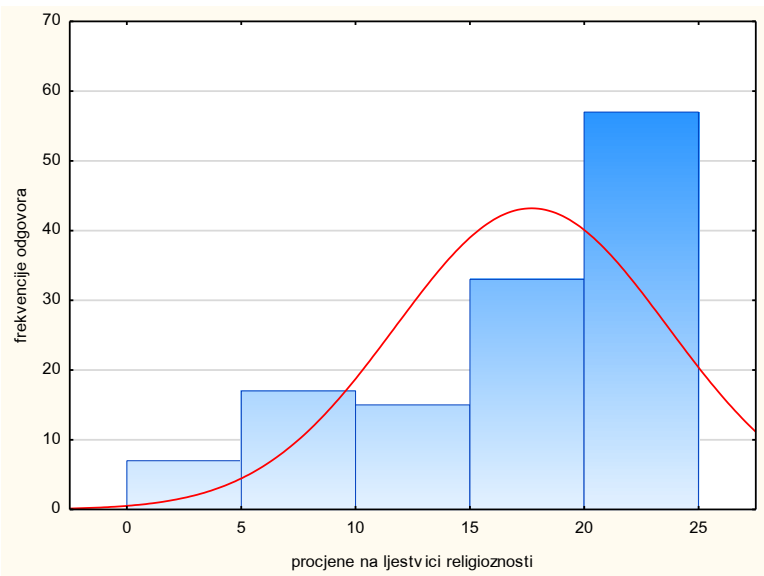

Grafikon 1 - grafički prikaz distribucije rezultata na ljestvici religioznosti

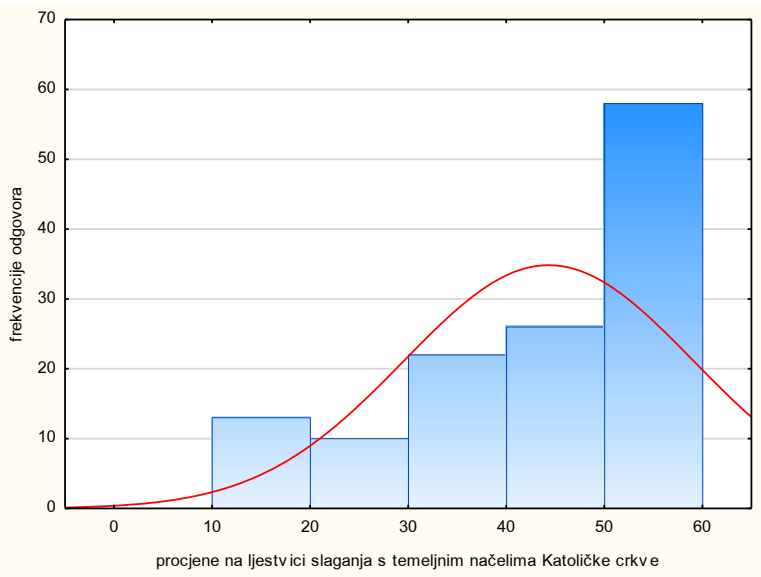

Grafikon 2 - Distribucija rezultata na ljestvici slaganja s TNBKC 
S obzirom da nam se prvo istraživačko pitanje odnosi na procjenu stupnja religioznosti mladih, posebno samo analizirani dobivene podatke na ove dvije ljestvice. Uvidom u visoku korelaciju između rezultata na kratkoj ljestvici religioznosti i ljestvici stupnja slaganja s TNBKC, odlučili smo se na analizu rezultata postignutih na ovoj posljednjoj ljestvici konstruiranoj posebno za ovo istraživanje. Na grafikonu 3 prikazane su frekvencije odgovora na pojedine tvrdnje ove ljestvice.

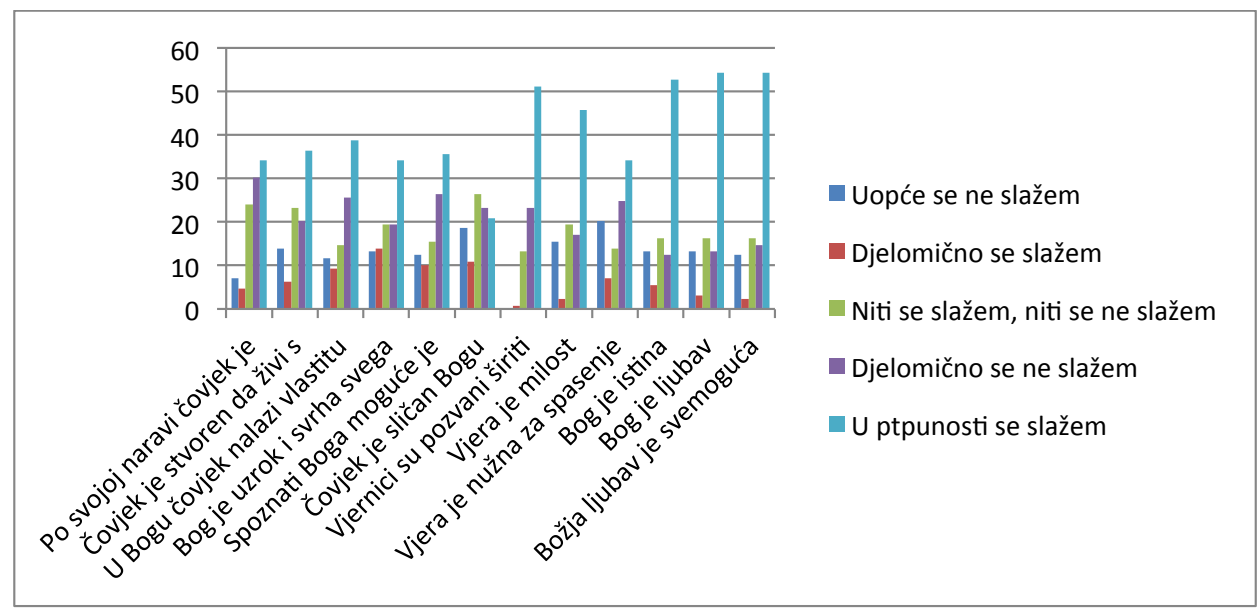

Grafikon 3 - prikaz frekvencija odgovora na pojedinim tvrdnjama na ljestvici slaganja s TNBKC

Iz grafičkog prikaza uočljivo je da se mladi najčešće djelomično i u potpunosti slažu s temeljnim načelima Katoličke crkve. Osobito se ističu tvrdnje Vjera je milost; Bog je istina; Bog je ljubav; Božja ljubav je svemoguća. Odgovori na istaknute tvrdnje u više od $50 \%$ mladih sudionika našeg istraživanja glase: $U$ potpunosti se slažem. Također se ističe tvrdnja Vjernici su pozvani širiti vjeru u živoga Boga, na koju 51,16 \% mladih odgovora da se u potpunosti slažu s njom.

Da bismo grupirali rezultate, sudionike istraživanja podijelili smo u dvije skupine. Prvu skupinu čine oni koji slaganje s TNBKC procjenjuju nižim vrijednostima od prosječne vrijednosti $(\mathrm{M})$, a drugu skupinu čine sudionici koji slaganje $\mathrm{s}$ temeljnim načelima procjenjuju više od prosječne vrijednosti (M). Uvidom $u$ postotke, možemo zaključiti da 41,86 \% mladih pripada prvoj skupini, odnosno oni svoje slaganje s TNBKC procjenjuju nižim od prosjeka, dok 58,14 \% mladih iskazuju svoje slaganje natprosječnim. Iz navedenog sa sigurnošću možemo reći da više od polovice sudionika istraživanja iskazuju viši stupanj slaganja s načelima na kojima se temelji Biblija i Katolička crkva. Dobiveni rezultati svakako idu u prilog rezultatima prije provedenog istraživanja koji govore o prosječno pozitivnim stavovima mladih prema vjeri u Republici Hrvatskoj. ${ }^{37}$

\footnotetext{
${ }^{37}$ Usp. Mandarić, Religiozno iskustvo u životu adolescenata..., 166.
} 
Zanimljivo je još jednom istaknuti da rezultati ovog istraživanja ne upućuju na razlike između religioznosti i slaganja s TNBKC s obzirom na spol. Naime, većina dosadašnjih istraživanja upućuju na suprotan zaključak i to u smislu veće religioznosti djevojaka, ${ }^{38}$ odnosno žena. ${ }^{39}$ Djevojke nešto češće idu na misu i prakticiraju vjeru. ${ }^{40}$ Rezultati ovoga istraživanja pokazuju razlike u prakticiranju vjere s obzirom na spol, ali te razlike nisu velike. Kao što je rečeno, rezultati ovog istraživanja utvrđuju da razlika u religioznosti i u slaganju s TNBKC nisu statistički značajne s obzirom na spol. Vrlo je važno istaknuti da pitanje istraživanja potencijalnih razlika s obzirom na spol nije jednostavno. Naime, polemizirajući o ovoj istraživačkoj temi Anić ističe da se razlike u religioznosti s obzirom na spol ponekad gube. ${ }^{41}$ Osobito je to slučaj kada se promatra i razina obrazovanja kao osobna značajka. Uzme li se ova varijabla u obzir, smanjuje se razlika u stupnju religioznosti između muškaraca i žena. ${ }^{42}$ Rezultati navedenog istraživanja upućuju na važnost obrazovanja i u religioznosti kod osoba višeg obrazovnog statusa, dok je spol kao varijabla važan prediktor religioznosti kod osoba nižeg obrazovnog statusa. ${ }^{43}$ Odgovor na pitanje o ne/postojanju razlika s obzirom na spol u stupnju religioznosti, svakako bi bio jasniji uključi li se složena sociodemografska slika. Također, važno je istaknuti da jedan od razloga ovakvih rezultata može biti relativno malen uzorak koji je ujedno i prigodan, dok drugi razlog može činiti utjecaj socijalizacije. Naime, možemo pretpostaviti da je promijenjen utjecaj sredine, između ostalog i na odnos prema vjeri. Nekada je bilo očekivano da žene aktivnije sudjeluju u životu Crkve u odnosu na muškarce. Međutim, danas su se promijenili trendovi očekivanja i od muškaraca i od žena pa pretpostavljamo da se to dogodilo i u odnosu prema vjeri te da su se »muškarci približili ‘ženskoj' religioznosti«. ${ }^{44}$ Rezultati nekih istraživanja upućuju upravo na značajno smanjenje razlike između muškaraca i žena u nekim indikatorima religioznosti ${ }^{45}$ ili čak nepostojanju razlike u općoj religioznosti s obzirom na spol. ${ }^{46}$

Prosječne vrijednosti koje mladi iskazuju na ljestvicama zadovoljstva životom i smisla života također dokazuju njihovo povećanje. Odnosno, mladi su

\footnotetext{
${ }^{38}$ Usp. Ivana BENDRA, Geran Marko MILETIĆ, Mateo ŽUNIĆ, Neki aspekti religioznosti srednjoškolaca iz Vukovarsko-srijemske županije i njihova povezanost s dominantnim vrijednosnim orijentacijama, Diacovensia, 28 (2020) 1, 27-54, 40.

${ }^{39}$ Usp. Bezinović, Marinović Bobinac, Marinović Jerolimov, Kratka ljestvica religioznosti...; Marinović Jerolimov, Religioznost, nereligioznost..., 147.

${ }^{40}$ Usp. Marinović Jerolimov, Religioznost, nereligioznost..., 105.

${ }^{41}$ Usp. Rebeka Jadranka ANIĆ, Spolne razlike u religioznosti pod vidom obrazovanja, Bogoslovska smotra, 78 (2008) 4, 873-903, 878.

${ }^{42}$ Usp. isto, 885.

${ }^{43}$ Usp. isto, 882.

${ }^{44}$ Usp. isto, 875.

${ }^{45}$ Usp. Goran ČRPIĆ, Siniša ZRINŠČAK, Dinamičnost u stabilnosti: Religioznost u Hrvatskoj 1999. i 2008. godine, Društvena istraživanja, 19 (2010) 1-2, 3-27, 19.

${ }^{46}$ Usp. Antonio DRAGUTIN, Povezanost religiozne orijentacije, seksualnosti i prosocijalnosti, Društvena istraživanja, 12 (2003) 1-2, 201-223, 221.
} 
uglavnom zadovoljni životom i svoj život procjenjuju smislenim, što je u skladu s prijašnjim istraživanjima. ${ }^{47}$ Ulazak $u$ ranu zrelu dob razvojni je period kada je očekivano da osoba ima definirane ciljeve i perspektivu pred sobom u smislu njihova ostvarivanja. Ovo je relativno stabilan period izlaska iz adolescencije, pri čemu se još nisu pojavila značajna egzistencijalna pitanja. Tijek školovanja još uvijek pruža sigurnost, a time uvjetuje stanovitu razinu zadovoljstva životom. Osim toga, ovakvi rezultati su optimistični, osobito ako ih gledamo u kontekstu zaključaka nekih istraživanja koji govore da se zadovoljstvo životom s obzirom na dob značajno ne mijenja. ${ }^{48}$

Sljedeće istraživačko pitanje odnosilo se na moguće razlike u zadovoljstvu životom u ovisnosti o stupnju slaganja s TNBKC. U tu svrhu koristili smo rezultate procjene na ljestvici slaganja s TNBKC podijeljene u dvije već spomenute kategorije i to u odnosu na prosječnu vrijednost (M). Rezultati t-testa za nezavisne uzorke koji su prikazani u tablici 2 pokazuju da mladi koji više pokazuju slaganje s TNBKC ujedno su i zadovoljniji životom.

Tablica 2 - Rezultati testiranja razlike u zadovoljstvu životom s obzirom na stupanj slaganja s TNBKC

\begin{tabular}{|c|c|c|}
\hline Slaganje s TNBKC & M & SD \\
\hline Manje & 63,46 & 9,33 \\
\hline Veće & 68,97 & 8,16 \\
\hline
\end{tabular}

$t_{(56)}=3,56, p=0,001$

Poput drugih sličnih istraživanja i mi zaključujemo da su religiozniji mladi ujedno i zadovoljniji životom, ${ }^{49}$ a u našem slučaju možemo zaključiti da mladi koji se više slažu s TNBKC ujedno su i zadovoljniji životom. Čini se da oni mladi koji su bliski Crkvi ne samo što svoj život ocjenjuju pozitivnim, već više uživaju u pozitivnim iskustvima u svakodnevnom životu. ${ }^{50}$

Sljedeće istraživačko pitanje odnosilo se na ispitivanje povezanosti između mjerenih varijabli, a rezultati korelacijske analize prikazani su u tablici 3.

Rezultati prikazani u tablici 3 pokazuju značajne korelacije između zadovoljstva životom i religioznosti i stupnja slaganja s TNBKC. Drugim riječima, mladi koji su religiozniji i u skladu s tim se više slažu s TNBKC, ujedno su i zadovoljniji životom. Takvi mladi su općenito zadovoljniji i imaju pozitivniji stav prema životu. O povezanosti višeg stupnja religioznosti i većega zadovoljstva životom svjedoče rezultati brojnih istraživanja. ${ }^{51}$ Čini se da je vjera u Boga važan izvor

\footnotetext{
${ }^{47}$ Usp. Brkljačić, Kaliterna Lipovčan, Zadovoljstvo životom..., 195.

${ }^{48}$ Usp. Chehregosha i dr., Life satisfaction index..., 49.

${ }^{49}$ Usp. Lim, Religion, Time...; Volkan YENIARAS, Tugra Nazil AKARUS, Religiosity and Life Satisfaction. A Multi-dimensional Approach, Journal of Happiness Studies, (2016), DOI 10.1007/ s10902-016-9803-4, 704 (31.03.2020).

${ }^{50}$ Usp. Lim, Religion, Time..., 701.

${ }^{51}$ Usp. Villani i dr., The Role of Spirituality..., 8; Lim, Religion, Time..., 704.
} 
podrške,$^{52}$ doprinosi uspješnijem suočavanju sa stresnim situacijama, ${ }^{53}$ te daje poticaj za zdrav način života. ${ }^{54}$

Tablica 3 - Rezultati analize povezanosti između mjerenih varijabli

\begin{tabular}{|l|c|c|c|c|}
\hline Varijable & $\begin{array}{c}\text { Zadovoljstvo } \\
\text { životom }\end{array}$ & Smisao života & $\begin{array}{c}\text { Slaganje s } \\
\text { TNBKC }\end{array}$ & Religioznost \\
\hline Zadovoljstvo životom & 1,00 & $0,69^{* * *}$ & $0,31^{* * *}$ & $0,32^{* * *}$ \\
\hline Smisao života & & 1,00 & 0,10 & 0,12 \\
\hline Slaganje s TNBKC & & & 1,00 & $0,91^{* * *}$ \\
\hline Religioznost & & & & 1,00 \\
\hline
\end{tabular}

$\mathrm{p}<0,001$

Rezultat koji pokazuje nepostojanje značajne povezanosti između procjene smisla života i religioznosti iznenađuje, ali i ne iznenađuje. Naime, čini se opravdanim pretpostaviti da su životni ciljevi mladih raznoliki i da nisu isključivo povezani s religioznošću. Pred njima su brojne mogućnosti i daleki horizonti potaknuti različitim aspiracijama, poput obrazovnih, poslovnih, partnerskih, koji ujedno čine sfere u kojima se planira budućnost. Međutim, istraživanja provedena na starijim osobama ukazuju na to da je religioznost značajno povezana s procjenom smisla života. $U$ usporedbi s osobama koje nisu vjernici i osobama koje su prema vjeri neutralne, vjernici - odnosno osobe koje su bliske $\mathrm{s}$ Bogom - smisao života procjenjuju značajno većim. ${ }^{55}$

Posljednje istraživačko pitanje odnosilo se na mogućnost predikcije zadovoljstva životom na temelju procjene religioznosti mladih, slaganja s TNBKC i procjene smisla života. Zbog visoke korelacije između rezultata postignutih na ljestvicama religioznosti i slaganja s TNBKC u regresijsku analizu smo uvrstili samo rezultate postignute na ljestvici slaganja s TNBKC. Rezultati su prikazani u tablici 4.

Tablica 4 - Rezultati regresijske analize kada je zadovoljstvo životom kriterij,

a prediktori slaganje s TNBKC i procjena smisla životom

\begin{tabular}{|l|l|}
\hline & Beta \\
\hline Slaganje s TNBKC & $0,24^{*}$ \\
\hline Smisao života & $0,66^{*}$ \\
\hline
\end{tabular}

$\mathrm{R}=0,73$

$\mathrm{R}^{2}=0,53$

$\mathrm{F}_{(2,126)}=71,11$

$\mathrm{p}=0,000 \mathrm{p}<0,05$

\footnotetext{
${ }^{52}$ Usp. Dušanić, Vujaković, Čekrlija, Uloga etnocentrizma, religioznosti..., 20.

${ }^{53}$ Usp. Bezinović, Marinović Bobinac, Marinović Jerolimov, Kratka ljestvica religioznosti..., 142.

${ }^{54}$ Usp. Julian CULVER, Melinda LUNDQUIST DENTON, Religious Attachment and the Sense of Life Purpose among Emerging Adults, Religions, 8 (2017) 12, 1-14 (274), 10; doi:10.3390/ rel8120274.

${ }^{55}$ Usp. isto, 10.
} 
Rezultati regresijske analize govore da su oba prediktora uvrštena u analizu značajna za predikciju zadovoljstva životom. Postotak objašnjene varijance zadovoljstva životom je prilično visok i iznosi 53 \%. Važno je istaknuti da procjena smisla života više doprinosi objašnjenju varijance zadovoljstva životom.

$\mathrm{Na}$ kraju treba istaknuti da je istraživanje religioznosti kod mladih vrlo važno područje istraživanja jer, kako smo vidjeli, značajno doprinosi zadovoljstvu životom mladih. U periodu formiranja identiteta, definiran sustav vrijednosti daje siguran okvir i zasigurno doprinosi osjećaju sigurnosti i predvidivosti. Dakako, religioznost je multidimenzionalan konstrukt. Istraživanja različitih dimenzija religioznosti također daju značajan doprinos razumijevanju povezanosti sa zadovoljstvom životom. Postoje još neka ograničenja ovog istraživanja. Relativno malen i prigodan uzorak ograničavaju generalizaciju dobivenih rezultata. Također, korelacijski tip istraživanja kao što je ovo ima svoja ograničenja. Longitudinalno istraživanje dalo bi bolji uvid u praćenje odnosa između religioznosti i zadovoljstva životom.

\section{Zaključak}

Cilj ovog istraživanja bio je ispitati ulogu religioznosti u psihološkoj dobrobiti mladih. U tu svrhu konstruirali smo mjerni instrument koji mjeri stupanj slaganja s TNBKC koji je pokazao zadovoljavajuću pouzdanost i valjanost.

Rezultati istraživanja pokazuju da nešto manje od $60 \%$ sudionika pokazuje natprosječno slaganje s TNBKC. Također, mladi koji su u toj kategoriji ujedno su i zadovoljniji životom. Dakako da je zadovoljstvo životom značajno povezano i s ostalim varijablama. Mladi koji su zadovoljniji životom imaju veći osjećaj smislenosti života i životne perspektive, religiozniji su i više se slažu s TNBKC. Smisao života i stupanj slaganja s TNBKC značajni su prediktori zadovoljstva životom.

Na koncu valja istaknuti da je istraživanje fenomena religioznosti i njegovih korelata od izuzetne znanstvene važnosti. Slojevitost i multidimenzionalnost religioznosti ovo istraživačko područje čini vrlo kompleksnim. Razumijevanje dinamike, razvoja i uloge religioznosti za dobrobit čovjeka daje doprinos promišljanju o još jednom aspektu razvoja koji značajno doprinosi kvaliteti života. Prenošenje i širenje biblijskih vrijednosti kroz formalni i neformalni sustav obrazovanja ima značajne praktične implikacije. 


\section{Mira Klarin* - Arkadiusz Krasicki** \\ Religiosity and some Dimensions of Psychological Well-being in Young People \\ Summary}

The aim of this research study was to investigate the role of religiosity in the psychological well-being of young people. For that purpose, a research study was conducted among young people of the average age of $20.74(\mathrm{~N}=129)$. The following measurement instruments were applied: Life Satisfaction Scale, Purpose in life Scale, Short Religiosity Scale, and the Scale of Agreement with the Basic Principles of the Bible and the Catholic Church. The results of the conducted study lead to the conclusion that the majority of young people are religious, i.e. that they agree with the basic biblical principles of the teachings of the Catholic Church. The results of the testing with regard to the difference in life satisfaction with reference to the level of agreement with the basic principles of the Bible and the Catholic Church indicate that the young people who agree with those principles to a greater extent are more satisfied with their life. Furthermore, life satisfaction has a positive correlation with the estimation of the purpose in life, religiosity, and the agreement with the basic principles of the Catholic Church. The results of the regression analysis indicate that the purpose in life and the agreement with the basic principles of the Bible and the Catholic Church are significant predictors of life satisfaction.

Key words: Bible, principles of the Catholic Church, religiosity, purpose in life, life satisfaction.

(na engl. prev. Antonija Šarić)

\footnotetext{
* Mira Klarin, PhD, Full Prof., University of Zadar, Department of Teachers and Preschool Teachers Education; Address: Ulica dr. F. Tuđmana 24i, HR-23000 Zadar, Croatia; E-mail: mklarin@ unizd.hr.

${ }^{* * *}$ Arkadiusz Krasicki, PhD, Assis. Prof., University of Zadar, Department of Religious Sciences; Address: Ulica dr. F. Tuđmana 24i, HR-23000 Zadar, Croatia; E-mail: arkadiusz.krasicki@ gmail.com.
} 